\title{
Pemodelan Faktor-Faktor yang Memengaruhi Gini Rasio Pembangunan di Jawa Timur dengan Regresi Spasial
}

\author{
Rosyita Darojati A'laa dan Sutikno \\ Departemen Statistika, Fakulats Matematika, Komputasi, dan Sains Data \\ Institut Teknologi Sepuluh Nopember (ITS) \\ e-mail: sutikno@statistika.its.ac.id
}

\begin{abstract}
Abstrak-Indonesia Attractiveness Index 2017 mengumumkan 5 besar provinsi terbaik, dimenangkan oleh provinsi Jawa Tengah, Sumatera Barat, D.I. Yogyakarta, Jawa barat dan Jawa Timur. Namun Provinsi Jawa Timur menduduki peringkat pertama untuk peningkatan nilai gini rasio. Gini rasio Provinsi Jawa Timur mengalami peningkatan dari 0,396 menjadi 0,415. Sebagai perbandingan, negara-negara di kawasan Timur Tengah dan Afrika Utara mengalami gejolak 'Arab Spring' ketika gini rasio sekitar 0,45. Belajar dari kasus tersebut ketimpangan pendapatan ini perlu penanganan serius dari pemerintah. Salah satunya dengan mengidentifikasi faktor-faktor yang memengaruhi ketimpangan pendapatan. Sehingga dalam Penelitian ini dilakukan pemodelan ketimpangan pendapatan kabupaten/kota di Jawa Timur dengan memper-timbangkan aspek spasial menggunakan regresi spasial. Hasil analisis yang diperoleh adalah ketimpangan pendapatan yang terjadi rata-rata termasuk dalam kondisi ketimpangan sedang. Model regresi spasial terbaik yang diperoleh adalah Spatial Error Model dengan nilai $R^{2}$ sebesar 46,6\% dan nilai RMSE sebesar 0.025713. Adapun variabel yang signifikan adalah variabel yang berasal dari aspek sosial yakni kepadatan penduduk dan tingkat pengangguran terbuka.
\end{abstract}

Kata Kunci-Gini rasio, Ketimpangan Pendapatan, Regresi Spasial.

\section{PENDAHULUAN}

$\mathrm{D}$ UA masalah besar yang umumnya dihadapi oleh negara-negara berkembang termasuk Indonesia adalah kesenjangan ekonomi atau ketimpangan dalam distribusi pendapatan antara kelompok masyarakat berpendapatan tinggi dan kelompok masyarakat berpendapatan rendah serta tingkat kemiskinan atau jumlah orang berada di bawah garis kemiskinan (poverty line) [1]. Ketimpangan harus mendapat perhatian karena ketimpangan wilayah yang ekstrim menyebabkan inefisiensi ekonomi, alokasi aset yang tidak efisien dan menambah jumlah kemiskinan, inefisiensi, melemahkan stabilitas sosial dan solidaritas dan memperkuat kekuatan politis golongan kaya sehingga menimbulkan ketidakadilan bagi masyarakat [2]. Berdasarkan Indonesia Attractiveness Index 2017, 5 besar provinsi terbaik dimenangkan oleh provinsi Jawa Tengah, Sumatera Barat, D.I. Yogyakarta, Jawa barat dan Jawa Timur. Namun bila dilihat dari ketimpangan pendapatan yang diukur menggunakan gini rasio, Provinsi Jawa Timur menduduki peringkat pertama diantara kelima provinsi tersebut untuk peningkatan nilai gini rasio.

Nilai Gini Rasio yang mendekati satu menunjukkan ketimpangan yang tinggi. Sehingga di Provinsi Jawa Timur saat ini mengalami ketimpangan pendapatan sedang dengan Gini Rasio terakhir sebesar 0.415. Walaupun termasuk kategori ketimpangan yang sedang, sejarah mengungkapkan bahwa negara-negara di kawasan Timur Tengah dan Afrika Utara mengalami gejolak 'Arab Spring' ketika gini rasio sekitar 0,45. Protes yang bernama Arab Spring ini menggunakan teknik pemberontakan sipil dalam kampanye yang melibatkan serangan, demonstrasi, pawai, dan pemanfaatan media sosial, seperti facebook, twitter, youtube, dan skype. Akumulasi dari berbagai kejadian telah turut mendukung dan memudahkan terjadinya Arab Spring. Namun, pemicu utamanya adalah situasi dan kondisi negara yang bersangkutan, yaitu kesenjangan sosial antara pemegang kekuasaan dan rakyat [3]. Belajar dari kasus tersebut penangan untuk kesenjangan yang terjadi di Jawa Timur perlu mendapat perhatian yang serius dari pemerintah.

Upaya untuk menekan besarnya gini rasio di Jawa Timur pasti akan dikaitkan dengan faktor-faktor yang mempengaruhinya. Penelitian mengenai ketimpangan pendapatan khususnya di Jawa timur sudah pernah dilakukan oleh Muhammad Arif dan Rossy Agustin W (2017) mengulas tentang Ketimpangan Pendapatan Propinsi Jawa Timur dan Faktor-faktor yang mempengaruhinya dengan metode regresi data panel. Kuncoro (2002) mengatakan bahwa selama kurang lebih satu abad, para pakar geografi, pakar ekonomi, perencana kota, para ahli strategi bisnis, ilmuwan regional dan ilmuwan lainnya telah mencoba memberikan penjelasan tentang mengapa dan dimana suatu aktivitas berlokasi. Sehingga semakin banyak fenomena-fenoma yang dikaji kembali dengan mempertimbangkan aspek spasialnya. Anselin (2003) menjelaskan apabila model regresi klasik digunakan sebagai alat analisis pada data spasial, maka bisa menyebabkan kesimpulan yang kurang tepat karena asumsi error saling bebas dan asumsi homogenitas tidak terpenuhi [4]. Karena data spasial mempunyai sifat dimana errornya saling berkorelasi dan terdapat pula spasial heterogenity sehingga dibutuhkan metode statistika untuk mengakomodir sifat tersebut. Sehingga dalam penelitian ini akan dilakukan pemodelan ketimpangan pendapatan kabupaten/kota di Jawa Timur dengan mempertimbangkan aspek spasialnya. Seperti yang diketahui, masing-masing kabupaten/kota di Jawa Timur memiliki sektor unggulan yang menjadi pemasukan utama pendapatan daerah. Terdapat pula beberapa daerah yang menjadi pusat perdagangan untuk beberapa wilayah disekitarnya. Sehingga diharapkan model regresi spasial yang terbentuk dapat lebih efektif dan informatif dalam menunjukkan aspek spasial mana yang dominan dalam permodelan Gini Rasio ini. 


\section{TINJAUAN PUSTAKA}

\section{A. Boxplot}

Boxplot merupakan ringkasan distribusi sampel yang disajikan secara grafis yang dapat menggambarkan bentuk distribusi data (skewness), ukuran tendensi sentral dan ukuran penyebaran penyebaran (keragaman) data pengamatan. Box and whisker plots atau lebih sering disebut dengan Boxplot atau box-plot (kotak-plot) saja. Seperti namanya, Box and Whisker, bentuknya terdiri dari box (kotak) dan whisker [4].

\section{B. Model Regresi Linier}

Metode regresi linier yang merupakan metode yang memodelkan hubungan antara variabel respon $y$ dan variabel prediktor $x_{1}, x_{2}, \ldots, x_{p}$. Model regresi linier untuk $p$ variabel prediktor secara umum ditulis sebagai berikut [5]:

$$
y_{i}=\beta_{0}+\beta_{1} x_{i 1}+\beta_{2} x_{i 2}+\cdots+\beta_{p} x_{i p}+\varepsilon_{i}
$$

dengan $i=1,2, \ldots, n ; \beta_{0}, \beta_{1}, \ldots, \beta_{p}$ adalah parameter model dan $\varepsilon_{1}, \varepsilon_{2}, \ldots, \varepsilon_{n}$ adalah error yang diasumsikan identik, independen, dan berdistribusi normal dengan mean nol dan varians konstan $\sigma^{2}$ atau $\left(\varepsilon_{i} \sim \operatorname{IIDN}\left(0, \sigma^{2}\right)\right)$.

Jika diambil sebanyak $n$ pengamatan, maka model untuk pengamatan ke- $i$ adalah:

$$
y_{i}=\beta_{0}+\sum_{k=1}^{p} \beta_{k} x_{i k}+\varepsilon_{i}
$$

dimana,

$y_{i} \quad$ : nilai observasi variabel respon pada pengamatan ke-i

$X_{i k}$ : nilai observasi variabel prediktor ke-k pada

$X_{i k}:$ pengamatan ke-i, dengan $\mathrm{k}=1,2, \ldots, \mathrm{p}$

$\beta_{0} \quad$ : nilai intersep model regresi

$\beta_{1} \quad$ : koefisien regresi variabel prediktor ke-k

$\varepsilon_{i} \quad$ : error pada pengamatan ke-i

Jika dituliskan dalam notasi matriks maka persamaan 1 menjadi:

$\mathbf{y}=\mathbf{X} \boldsymbol{\beta}+\boldsymbol{\varepsilon}$

dengan:

$\mathbf{y}=\left(\begin{array}{c}y_{1} \\ y_{2} \\ \vdots \\ y_{n}\end{array}\right), \mathbf{X}=\left(\begin{array}{lllll}1 & x_{11} & x_{12} & \cdots & x_{1 p} \\ 1 & x_{21} & x_{22} & \cdots & x_{2 p} \\ \vdots & \vdots & \vdots & \ddots & \vdots \\ 1 & x_{n 1} & x_{n 2} & \cdots & x_{n p}\end{array}\right), \boldsymbol{\beta}=\left(\begin{array}{c}\beta_{0} \\ \beta_{1} \\ \vdots \\ \beta_{p}\end{array}\right), \quad \boldsymbol{\varepsilon}=\left(\begin{array}{c}\varepsilon_{1} \\ \varepsilon_{2} \\ \vdots \\ \varepsilon_{n}\end{array}\right)$

Sedangkan nilai estimasi untuk $\mathbf{y}$ dan $\boldsymbol{\varepsilon}$ adalah:

$$
\hat{\mathbf{y}}=\mathbf{X} \hat{\boldsymbol{\beta}} \text { dan } \hat{\boldsymbol{\varepsilon}}=\mathbf{y}-\hat{\mathbf{y}}=\mathbf{y}-\mathbf{X} \hat{\boldsymbol{\beta}}
$$

dimana,

$$
\mathbf{y} \quad \text { : vektor observasi variabel respon berukuran } \mathrm{n} \times 1
$$

$\mathbf{X}$ : matriks variabel prediktor berukuran $\mathrm{n} x(\mathrm{p}+1)$

及 : vektor parameter berukuran $(\mathrm{p}+1) \mathrm{x} 1$

$\boldsymbol{\varepsilon} \quad$ : vektor error berukuran $\mathrm{n} \times 1$

Untuk menguji kesesuaian model regresi OLS digunakan analisis varian yang dibuat dengan cara menguraikan bentuk jumlah kuadrat total atau Sum Square Total (SST) menjadi dua komponen: Jumlah kuadrat regresi atau Sum Square Regression (SSR) dan Jumlah Kuadrat Error atau Sum Square Error (SSE).Hipotesisnya adalah:

$$
\begin{aligned}
& H_{0}: \beta_{1}=\beta_{2}=\ldots=\beta_{p}=0 \\
& H_{1}: \text { minimal ada satu } \beta_{k} \neq 0
\end{aligned}
$$

Tabel 1.

Analisis Varians Model Regresi[6]

\begin{tabular}{ccccc}
\hline \hline Sumber Variasi & Jumlah Kuadrat & db & Rata-rata Kuadrat & F Hitung \\
\hline Regresi & $\mathbf{y}^{T}\left(\mathbf{H}-\frac{1}{n} \mathbf{J}\right) \mathbf{y}$ & $p$ & $M S R=\frac{S S R}{p}$ & $F=\frac{M S R}{M S E}$ \\
Error & $\mathbf{y}^{T}(\mathbf{I}-\mathbf{H}) \mathbf{y}$ & $n-(p+1)$ & $M S E=\frac{S S E}{n-(p+1)}$ & \\
Total & $\mathbf{y}^{T}\left(\mathbf{I}-\frac{1}{n} \mathbf{J}\right)$ & $n-1$ & & \\
\hline \hline
\end{tabular}

J adalah matriks berukuran nxn dengan semua elemen bernilai 1.Dalam pengambilan keputusan, Tolak $\mathrm{H}_{0}$ bila $F_{\text {hitung }}$ kurang dari $F_{\alpha, p,(n-p-1)}$ atau $P$-value $<\alpha$. Adapun pengujian secara parsial untuk mengetahui parameter mana saja yang signifikan terhadap model dilakukan dengan hipotesis:

$H_{0}: \beta_{k}=0$

$H_{1}: \beta_{k} \neq 0$

Statistik uji dalam pengujian parsial ini adalah $t=\frac{\hat{\beta}_{k}}{\operatorname{se}(\hat{\beta})_{k}}$ [6]. $\operatorname{se}\left(\hat{\beta}_{k}\right)=s \sqrt{g_{k k}}$ adalah standar error dari koefisien $\hat{\beta}_{k}$. Sedangkan $g_{k k}$ adalah elemen diagonal ke- $k$ dari matriks $\left(\mathbf{X}^{\mathbf{T}} \mathbf{X}\right)^{-1}$ dan $\mathbf{s}=\sqrt{M S E}$. Dibawah $\mathrm{H}_{0}, \boldsymbol{t}$ akan mengikuti distribusi $\boldsymbol{t}$ dengan derajat bebas $(n-p-1)$ sehingga jika diberikan tingkat signifikansi sebesar $\alpha$ maka diambil keputusan tolak $\mathrm{H}_{0}$ jika

$\left|t_{h i t}\right|>t_{\alpha / 2 ; n-p-1}$

\section{Principal Component Analysis (PCA)}

Principal Component Analysis (PCA) adalah suatu metode analisis multinomial, yang bertujuan untuk mengurangi dimensi variabel yang diamati, yang saling berkorelasi satu sama lain, sehingga menjadi variabel baru (disebut dengan komponen utama) yang berukuran lebih kecil, namun mampu menerangkan sebagian besar keragaman total data, dan saling bebas satu sama lain [7]. PCA mereduksi dimensi data dengan cara mentranformasi variabel-variabel asli yang berkorelasi menjadi satu set variabel baru yang tidak berkorelasi, dengan tetap mempertahankan sebanyak mungkin keragaman yang dapat dijelaskan. Variabel-variabel baru itu disebut sebagai Principal Component (PC) [8].

Secara aljabar PCA adalah kombinasi linear dari $\mathrm{p}$ variabel random $\mathbf{X}^{\prime}=\left[\mathrm{X}_{1}, \mathrm{X}_{2}, \ldots, \mathrm{X}_{\mathrm{p}}\right]$. Kombinasi linear ini adalah seleksi dari koordinat baru dari rotasi variabel asal $\left[\mathrm{X}_{1}, \mathrm{X}_{2}, \ldots, \mathrm{X}_{\mathrm{p}}\right.$ ] sebagai sumbu koordinat [8]. Sumbu baru ini mampu menjelaskan variasi maksimum dan menghasilkan penjelasan yang lebih simpel dan hemat dari struktur kovarian. Syarat untuk membentuk PC yang merupakan kombinasi linear dari variabel $\mathbf{X}$ agar mempunyai keragaman yang besar adalah dengan memilih $e_{i}{ }^{\prime}=\left(e_{1} e_{2} \ldots\right.$ $\left.e_{p}\right)$ sedemikian hingga var $\left(e_{i}{ }^{\prime} \mathbf{X}\right)$ maksimum dan $e_{i}{ }^{\prime} e_{i}=1$ dan $\operatorname{cov}\left(\mathrm{e}_{\mathrm{i}}{ }^{\prime} \mathbf{X}, \mathrm{e}_{\mathrm{k}}{ }^{\prime} \mathbf{X}\right)=0$ untuk $\mathrm{k}<\mathrm{i}$.

PC dapat diperoleh dari pasangan eigenvalueeigenvektor matriks kovarian maupun matriks korelasi. Jika satuan variabel asal tidaksama, perlu dilakukan pembakuan data terlebih dahulu. Akibat adanya pembakuan data ini maka matriks varians kovarians $(\Sigma)$ dari data yang dibakukan akan sama dengan matriks korelasi (R) data sebelum dibakukan dan besarnya total varians komponen utama sama dengan banyaknya variabel asal p. Random vektor populasi $\mathbf{X}=[\mathbf{X} 1, \mathbf{X} 2, \ldots, \mathbf{X p}]^{\mathrm{t}}$ berdistribusi 
multivariate normal dengan vektor mean $\boldsymbol{\mu}=\left[\boldsymbol{\mu}_{1}, \boldsymbol{\mu}_{2}, \ldots, \boldsymbol{\mu}_{\mathrm{p}}\right]^{\mathrm{t}}$ dan matriks varians kovarian $\mathbf{S}$ dengan akar ciri (eigen value) berturut-turut adalah yaitu $\lambda_{1}>\lambda_{2}>\ldots>\lambda_{p}>0$, maka kombinasi linear utama adalah sebagai berikut :

$$
\begin{aligned}
& Y_{1}=\mathbf{e}_{1}{ }^{\prime} \mathbf{X}=e_{11} X_{1}+e_{21} X_{2}+\ldots+e_{p 1} X_{p} \\
& Y_{2}=\mathbf{e}_{2}{ }^{\prime} \mathbf{X}=e_{12} X_{1}+e_{22} X_{2}+\ldots+e_{p 2} X_{p} \\
& Y_{p}=\mathbf{e}_{p}{ }^{\prime} \mathbf{X}=e_{1 p} X_{1}+e_{2 p} X_{2}+\ldots+e_{p p} X_{p}
\end{aligned}
$$$$
\text { dengan, }
$$

$Y_{1}$ : PC Pertama, yang mempunyai varians terbesar

$Y_{2}$ : PC ke-2, yang mempunyai varians terbesar ke-2

$Y_{p}$ : PC ke-p, yang mempunyai varians terbesar ke-p

X : Vektor Random Variabel Asal (X)

$\mathbf{e}_{p}:$ Vektor karakteristik data ke-p, dimana $\mathbf{e}=|\lambda \mathbf{I}-\mathbf{A}| \mathbf{X}=0$

Model PC ke-i secara umum dapat ditulis $Z_{i}=e_{i}{ }^{\prime} \mathbf{X}$, dimana: $\mathrm{i}=1,2, \ldots, \mathrm{p}$ sehingga,

$\operatorname{Var}\left(Z_{i}\right)=e_{i}{ }^{\prime} \sum e_{i}, i=1,2, \ldots, p$

$\operatorname{Cov}\left(Z_{i}, Z_{k}\right)=e_{i}{ }^{\prime} \sum e_{k}, i \neq k$

Dari penjelasan sebelumnya menunjukkan sifat-sifat PC yaitu:

a. Komponen pertama Y1 memuat variasi maksimum data dan seterusnya seperti uraian sebelumnya. Variasi maksimum diperoleh dari rumusan hasil eigen value, dimana $\lambda 1$ adalah menunjukkan keragaman terbesar. Sehingga hasil komponen pertama juga akan menghasilkan keragaman paling besar.

b. $e_{i 1}^{2}+e_{i 2}^{2}+\ldots+e_{i p}^{2}=1 ; i=1,2, \ldots, p$

c. $e_{i 1} e_{j 1}+e_{i 2} e_{j 2}+\ldots+e_{i p} e_{j p}=0 ; i \neq p$

Berdasarkan rumus $\mathrm{b}$ dan $\mathrm{c}$ maka,

$\sigma_{11}+\sigma_{22}+\ldots+\sigma_{p p}=\sum_{i=1}^{p} \operatorname{Var}\left(X_{i}\right)=\operatorname{tr}(\Sigma)=\lambda_{1}+\lambda_{2}+\ldots+\lambda_{p}$

Hal ini disebabkan sifat PC tidak berkorelasi dan mempunyai varians yang sama dengan eigen value dari $\Sigma$. Sehungga total varians populasi adalah

$\sigma_{11}+\sigma_{22}+\ldots+\sigma_{p p}=\lambda_{1}+\lambda_{2}+\ldots+\lambda_{p}$

Jadi persentase keragaman total yang dapat diterangkan oleh komponen utama ke-I adalah sebagai berikut;

Proporsi varians ke-i $=\frac{\lambda_{i}}{\lambda_{1}+\lambda_{2}+\ldots+\lambda_{p}}$

Apabila PC yang diambil sebanyak k dimana $(\mathrm{k}<\mathrm{p})$, maka :

Proporsi varians $\mathrm{k} P \mathrm{PC}=\frac{\lambda_{1}+\lambda_{2}+\ldots+\lambda_{k}}{\lambda_{1}+\lambda_{2}+\ldots+\lambda_{p}}$

\section{Pembobot Spasial}

Matriks pembobot spasial (W) dapat diperoleh berdasarkan informasi jarak dari ketetanggaan (neighborhood) atau jarak antara satu lokasi dengan lokasi lain. Ada beberapa metode untuk mendefinisikan hubungan persinggungan (contiguity) antar lokasi tersebut [9] antara lain;

1. Linear contiguity (persinggungan tepi)

2. Rook contiguity (persinggungan sisi)

3. Bhisop Contiguity (Persinggungan sudut)

4. Double linear Contiguity (Persinggungan dua tepi)

5. Double rook Contiguity (Persinggungan dua sisi)

6. Queen contiguity (persinggungan sisi-sudut)

E. Pengujian Dependensi Spasial

Nilai Moran'S I adalah indeks yang menunjukkan dependensi spasial dalam residual $\varepsilon_{\mathrm{i}}$.
Hipotesis yang digunakan adalah,

$\mathrm{H}_{0} \quad: \mathrm{I}=0$ (Tidak ada autokorelasi antar lokasi)

$\mathrm{H}_{1} \backslash: \mathrm{I} \neq 0$ (Ada Autokorelasi antar lokasi )

Statistik uji yang digunakan,

$$
Z_{\text {hit }}=\frac{\hat{\mathrm{I}}-\mathrm{E}(\hat{I})}{\sqrt{\operatorname{Var}(\hat{I})}}
$$

dimana,

$$
\begin{aligned}
& \hat{I}=\frac{n \sum_{i=1}^{n} \sum_{j=1}^{n} w_{i j}\left(x_{i}-\bar{x}\right)\left(x_{j}-\bar{x}\right)}{S_{0} \sum_{i=1}^{n}\left(x_{i}-\bar{x}\right)^{2}} \\
& \mathrm{E}(\hat{I})=-\frac{1}{n-1} \\
& \operatorname{Var}(\hat{I})=\frac{n\left[\left(n^{2}-3 n+3\right) S_{1}-n S_{2}+2 S_{0}^{2}\right]}{(n-1)(n-2)(n-3) s_{0}^{2}}-\frac{k\left[\left(n^{2}-n\right) S_{1}-n S_{2}+3 S_{0}^{2}\right]}{(n-1)(n-2)(n-3) S_{0}^{2}}-\left[\frac{-1}{n-1}\right]^{2} \\
& k=\frac{\sum_{i=1}^{n}\left(x_{i}+\bar{x}\right)^{4}}{\left(\left(\sum_{i=1}^{n} x_{i}-\bar{x}\right)^{2}\right)^{2}} \\
& S_{0}=\sum_{i=1}^{n} \sum_{j=1}^{n} w_{i j} \\
& S_{1}=\frac{\sum_{i=1}^{n} \sum_{j=1}^{n}\left(w_{i j}+w_{j i}\right)^{2}}{2} \\
& S_{2}=\sum_{i=1}^{n}\left(\sum_{j=1}^{n} w_{i j}+\sum_{j=1}^{n} w_{j i}\right)^{2}
\end{aligned}
$$

Pengambilan keputusannya adalah $\mathrm{H}_{0}$ ditolak jika $\mathrm{Z}_{\text {hit }}>\mathrm{Z}_{\alpha / 2}$ atau P-value kurang dari $\alpha$

\section{F. Pengujian Heterogenitas Spasial}

Metode uji Breusch-Pagan dapat digunakan untuk menguji heterogenitas spasial (spatial heterogeneity) [10]. Hipotesisnya adalah:

$\mathrm{H}_{0}: \sigma_{1}^{2}=\sigma_{2}^{2}=\ldots=\sigma_{n}^{2}=\sigma^{2}$ (homoskedastisitas, karakteristik di suatu lokasi homogen)

$\mathrm{H}_{1}$ : minimal ada satu $\sigma_{i}^{2} \neq \sigma^{2}$ (heterokedastisitas,

Karakteristik di suatu lokasi heterogen)

Statistik Uji :

$$
B P=\left(\frac{1}{2}\right) \mathbf{r}^{T} \mathbf{Z}\left(\mathbf{Z}^{T} \mathbf{Z}\right)^{-1} \mathbf{Z}^{T} \mathbf{f}
$$

Dengan elemen vektor $\mathbf{f}$ adalah :

$$
f_{i}=\left(\frac{e_{i}^{2}}{\sigma^{2}}-1\right)
$$

dimana,

$e_{i} \quad$ : residual least square untuk observasi ke-i

$\mathbf{Z}$ : merupakan matriks berukuran $n \times(p+1)$ yang berisi vektor yang sudah di normal standarkan (Z) untuk setiap observasi

Tolak $\mathrm{H}_{0}$ bila $B P>\chi_{(p)}^{2}$ atau jika $\mathrm{P}$-value $<\alpha$ dengan $\mathrm{p}$ adalah banyaknya prediktor.

\section{G. Regresi Spasial Basis Area}

Berdasarkan rujukan [10] Anselin mengembangkan suatu General spatial model dengan menggunakan data spatial cross section. General spatial model sendiri merupakan model spasial yang merupakan kombinasi antara atoregressive dan moving average atau biasa disebut dengan Spatial Autoregressive Moving Average (SARMA). Bentuk umumnya ditunjukkan dengan persamaan berikut ini:

$$
\mathbf{y}=\rho \mathbf{W}_{\mathbf{1}} \mathbf{y}+\mathbf{X} \boldsymbol{\beta}+\mathbf{u} \quad \mathbf{u}=\lambda \mathbf{W}_{2} \mathbf{u}+\boldsymbol{\varepsilon}
$$

dimana, $\boldsymbol{\varepsilon} \sim \mathrm{N}\left(0, \sigma^{2} \mathbf{I}\right), \mathbf{y}$ merupakan vektor variabel respon yang memiliki ketergantungan secara spasial dengan ukuran $n x 1$ dan $X$ adalah matriks variabel prediktor dengan ukuran $n x k$. $\boldsymbol{\beta}$ adalah parameter model regresi yang berbentuk 
vektor dengan ukuran $(p+1) x 1 . \rho$ adalah koefisien spasial lag dari variabel respon, $\lambda$ merupakan koefisien pada struktur autoregressive spasial dalam error $\varepsilon$. $\mathbf{W}_{\mathbf{1}}$ dan $\mathbf{W}_{\mathbf{2}}$ merupakan matrik penimbang spasial berukuran $\left(\begin{array}{lll}n & \mathrm{x} & n\end{array}\right)$ dengan elemen diagonalnya bernilai 0 . Beberapa model turunan bisa diperoleh dari model General spatial model diatas, yaitu:

1. Model regresi linier OLS, diperoleh apabila nilai $\rho=0$ dan $\lambda=0$, dimana model General spatial model berubah menjadi:

$$
\mathbf{y}=\mathbf{x} \boldsymbol{\beta}+\boldsymbol{\varepsilon}
$$

2. Model Spatial Autoregressive Model atau Dependensi Spasial Lag (Spatial Lag Model, SLM), diperoleh apabila nilai $\rho \neq 0$ dan $\lambda=0$, sehingga modelnya menjadi:

$$
\mathbf{y}=\rho \mathbf{W}_{1} \mathbf{y}+\mathbf{X} \boldsymbol{\beta}+\mathbf{u}
$$

3. Model Spatial Autoregressive Model atau Dependensi Spasial Lag (Spatial Lag Model, SLM), diperoleh apabila nilai $\rho \neq 0$ dan $\lambda=0$, sehingga modelnya menjadi:

$$
\mathbf{y}=\mathbf{X} \boldsymbol{\beta}+\mathbf{u} ; \mathbf{u}=\lambda \mathbf{W}_{2} \mathbf{u}+\boldsymbol{\varepsilon}
$$

H. Pengukuran Kebaikan Model

1. Koefisien determinasi $\left(\mathrm{R}^{2}\right)$

$$
\mathrm{R}^{2}=1-\frac{S S E}{S S T}
$$

Model terbaik ditunjukkan dengan nilai $\mathrm{R}^{2}$ yang tinggi untuk setiap unit variabel prediktor dipertimbangkan.

2. Root Mean Square Error(RMSE)

$$
\mathrm{RMSE}=\sqrt{\frac{1}{n} \sum_{i=1}^{n}\left(y_{i}-\hat{y}\right)^{2}}
$$

dengan

$$
\begin{aligned}
& n=\text { banyaknya observasi } \\
& y_{i}=\text { nilai observasi ke-i } \\
& \hat{y}_{i}=\text { nilai prediksi ke-i }
\end{aligned}
$$

\section{Ketimpangan Pendapatan}

Ketimpangan merupakan hal yang tidak sebagaimana mestinya seperti tidak adil, tidak beres. Sedangkan, pendapatan adalah seluruh penghasilan yang diterima baik sektor formal maupun non formal yang terhitung dalam jangka waktu tertentu . Distribusi pendapatan mencerminkan ketimpangan atau meratanya hasil pembangunan suatu daerah atau negara baik yang diterima masing masing orang ataupun dari kepemilikan faktor-faktor produksi dikalangan penduduknya. Distribusi pendapatan yang didasarkan pada pemilik faktor produksi ini akan berkaitan dengan proses pertumbuhan pendapatan, adapun pertumbuhan pendapatan dalam masyarakat yang didasarkan pada kepemilikan faktor produksi dapat dikelompokkan menjadi dua macam:

1. Pendapatan karena hasil kerja yang berupa upah atau gaji dan besarnya tergantung tingkat produktifitas.

2. Pendapatan dari sumber lain seperti sewa, laba, bunga, hadiah atau warisan.

\section{METODOLOGI PENELITIAN}

\section{A. Sumber Data}

Data yang digunakan dalam penelitian ini merupakan data sekunder yang dipublikasikan oleh BPS Provinsi Jawa Timur. Data tersebut diperoleh dari publikasi yang berupa Jawa Timur dalam Angka tahun 2012-2015 dan Statistik
Daerah Kabupaten/Kota 2012-2015 dengan unit observasi sejumlah 30 Kabupaten dan 8 Kota.

\section{B. Variabel Penelitian}

Variabel yang digunakan dalam penelitian ini terdiri dari 1 variabel dependen dan 29 variabel independen.

Tabel 2.

Variabel dan Skala pengukuran

\begin{tabular}{cll}
\hline \hline Notasi & & \multicolumn{1}{c}{ Nama Variabel } \\
\hline $\mathrm{Y}_{1}$ & Gini Rasio & Skala \\
$\mathrm{X}_{1}$ & Indeks Kesehatan & Rasio \\
$\mathrm{X}_{2}$ & Indeks Pendidikan & Rasio \\
$\mathrm{X}_{3}$ & Tingkat Partisipasi Angkatan Kerja & Rasio \\
$\mathrm{X}_{4}$ & Persentase Penduduk Miskin & Rasio \\
$\mathrm{X}_{5}$ & Kepadatan Penduduk & Rasio \\
$\mathrm{X}_{6}$ & Tingkat Partisipasi SD & Rasio \\
$\mathrm{X}_{7}$ & Tingkat Partisipasi SMP & Rasio \\
$\mathrm{X}_{8}$ & Tingkat Partisipasi SMA & Rasio \\
$\mathrm{X}_{9}$ & Tingkat Penganggguran Terbuka & Rasio \\
$\mathrm{X}_{10}$ & PDRB Pertanian, Kehutanan, Perikanan & Rasio \\
$\mathrm{X}_{11}$ & PDRB Pertambangan dan Penggalian & Rasio \\
$\mathrm{X}_{12}$ & PDRB Industri Pengolahan & Rasio \\
$\mathrm{X}_{13}$ & PDRB Konstruksi & Rasio \\
$\mathrm{X}_{14}$ & PDRB Perdagangan Besar \& Eceran, Reparasi Mobil & Rasio \\
$\mathrm{X}_{15}$ & PDRB Penyediaan Akomodasi dan Makan Minum & Rasio \\
$\mathrm{X}_{16}$ & PDRB Jasa Keuangan dan Asuransi & Rasio \\
$\mathrm{X}_{17}$ & PDRB Real Estate & Rasio \\
$\mathrm{X}_{18}$ & PDRB Jasa Perusahaan & Rasio \\
$\mathrm{X}_{19}$ & PDRB Adm.Pemerintah, Pertahanan \& JamSos Wajib & Rasio \\
$\mathrm{X}_{20}$ & PDRB Jasa Pendidikan & Rasio \\
$\mathrm{X}_{21}$ & PDRB Jasa Kesehatan dan Keg.Sosial & Rasio \\
$\mathrm{X}_{22}$ & PDRB Jasa Lainnya & Rasio \\
$\mathrm{X}_{23}$ & Investasi & Rasio \\
$\mathrm{X}_{24}$ & Indeks Daya Beli & Rasio \\
$\mathrm{X}_{25}$ & Pertumbuhan PDRB & Rasio \\
$\mathrm{X}_{26}$ & PDRB Pengadaan Listrik dan Gas & Rasio \\
$\mathrm{X}_{27}$ & PDRB Pengadaan Air, Pengelolaan Sampah, Limbah & Rasio \\
$\mathrm{X}_{28}$ & PDRB Transportasi dan Pergudangan & Rasio \\
$\mathrm{X}_{29}$ & PDRB Informasi Komunikasi & Rasio \\
\hline \hline & & Rasio \\
\hline
\end{tabular}

\section{Struktur Data}

Berikut ini merupakan struktur data penelitian dan kerangka konsep penelitian,

Tabel 3.

Struktur Data Penelitian

\begin{tabular}{ccccccc}
\hline \hline Kab/Kota & $\mathrm{Y}$ & $\mathrm{X}_{1}$ & $\mathrm{X}_{2}$ & $\ldots$ & $\mathrm{X}_{29}$ \\
\hline \multicolumn{1}{c}{$(1)$} & $(2)$ & $(3)$ & $(4)$ & $\ldots$ & $(31)$ \\
Pacitan & 0,31 & 0,78 & 0,54 & $\ldots$ & 0,063 \\
Ponorogo & 0,31 & 0,8 & 0,59 & $\ldots$ & 0,082 \\
Trenggalek & 0,31 & 0,81 & 0,55 & $\ldots$ & 0,06 \\
$\vdots$ & $\vdots$ & $\vdots$ & $\vdots$ & $\ddots$ & $\vdots$ \\
Sumenep & 0,25 & 0,77 & 0,5 & $\ldots$ & 0,047 \\
\hline \hline
\end{tabular}

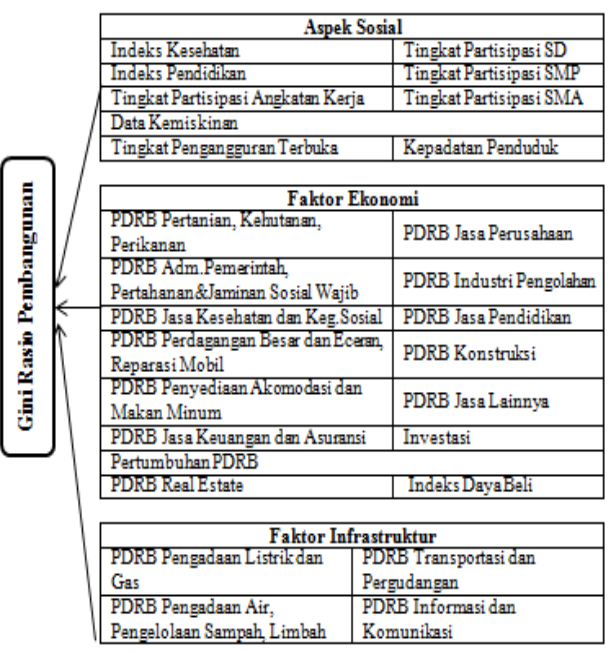

Gambar 1. Model Konseptual Gini Rasio. 


\section{Langkah Analisis}

Langkah-langkah dalam analisis data untuk mencapai setiap tujuan penelitian adalah sebagai berikut,

a) Mendeskripsikan gini rasio pembangunan antar kabupaten/kota di Jawa Timur

1. Mengeksplorasi Variabel Y dengan menggunakan Boxplot dan Peta Tematik.

2. Interpretasi hasil

b) Mendapatkan model terbaik gini rasio pembangunan antar kabupaten/kota di Jawa Timur

1. Melakukan pemodelan regresi OLS

2. Pengujian efek spasial, uji dependensi spasial dan uji heterogenitas spasial menggunakan Breusch Pagan Test dan Uji Moran's I.

3. Melakukan pemodelan regresi spasial dengan menggunakan pendekatan area.

4. Pemilihan model terbaik dengan RMSE dan $\mathrm{R}^{2}$

5. Interpretasi hasil serta penarikan kesimpulan.

\section{ANALISIS DAN PEMBAHASAN}

\section{A. Karakteristik Data Gini Rasio Pembangunan di Jawa}

Timur

Secara Administratif Jawa Timur terbagi menjadi 29 Kabupaten dan 9 kota, dengan kota Surabaya sebagai Ibukota Provinsi. Adapun karakteristik ketimpangan pendapatan kabupaten/kota di Provinsi Jawa Timur berdasarkan Gini Rasio pembangunan diklasifikasikan dalam 3 kategori yakni rendah, sedang, dan tinggi.

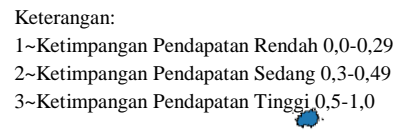

1 Ketimpangan Pendapatan Rendah 0,0-0,29

2 Ketimpangan Pendapatan Sedang 0,3-0,49

3 Ketimpangan Pendapatan Tinggi $0,5-1,0$
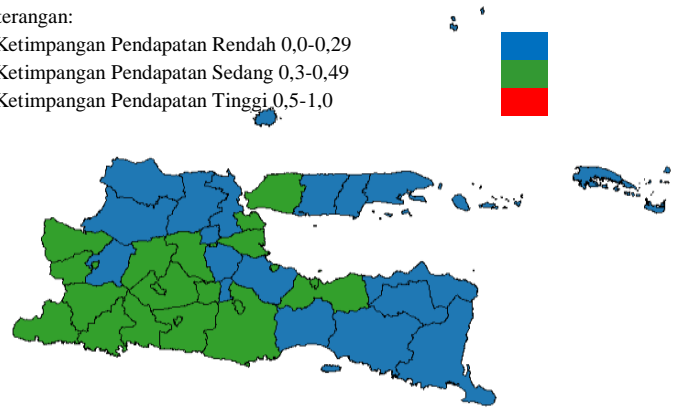

Gambar 2. Peta Tematik Gini Rasio di Provinsi Jawa Timur.

Berdasarkan Gambar 2 dapat terlihat bahwa sebagian besar daerah mengalami kondisi ketimpangan sedang. Ketimpangan pendapatan kategori rendah memiliki persebaran yang mengelompok dan terjadi pada 16 wilayah kabupaten/kota. Wilayah tersebut meliputi daerah yang berada di pantai utara jawa, daerah yang termasuk wilayah tapal kuda dan sebagian wilayah di Pulau Madura. Sedangkan untuk Ketimpangan Pendapatan kategori sedang terlihat tersebar pada daerah yang berada di Pantai selatan dan beberapa daerah yang dekat dengan Kota Surabaya seperti Kabupaten Bangkalan dan Kabupaten Sidoarjo serta wilayah lain yang berstatus sebagai kotamadya.

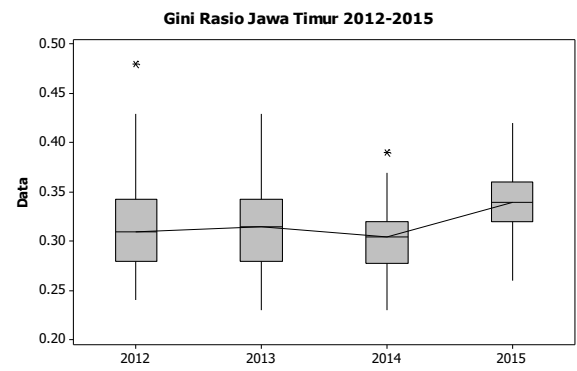

Gambar 3. Boxplot Gini Rasio Jawa Timur
Gambar 3 menunjukkan historis nilai Gini Rasio di wilayah Jawa Timur masih termasuk dalam kategori ketimpangan rendah dan sedang. Namun dapat dilihat pada tahun 2015 tejadi pergeseran median dan nilai observasi secara keseluruhan nilainya lebih tinggi daripada 3 tahun sebelumnya. Hal ini membuktikan bahwa ketimpangan pendapatan di wilayah Provinsi Jawa Timur meningkat pada tahun 2015.

\section{B. Pemilihan Model Regressi Spasial Terbaik}

Analisis regresi linier berganda digunakan untuk mengetahui hubungan antara variabel dependen dan independen secara linier. Namun sebelum melakukan pemodelan dilakukan pengecekan nilai VIF untuk masingmasing variabel prediktor agar dapat diketahui apakah terdapat kasus multikolinieritas antar variabel prediktor atau tidak.. Nilai VIF seluruhnya terangkum dalam tabel 4.4,

Tabel 4.

Nilai VIF untuk 29 Variabel Prediktor

\begin{tabular}{cccccc}
\hline \hline Variabel & $R$-square & VIF & Variabel & $R$-square & $V I F$ \\
\hline $\mathrm{X}_{1}$ & 0,84 & 6,135 & $\mathrm{X}_{15}$ & 1,00 & 1000 \\
$\mathrm{X}_{2}$ & 0,98 & 45,455 & $\mathrm{X}_{16}$ & 1,00 & 1000 \\
$\mathrm{X}_{3}$ & 0,77 & 4,405 & $\mathrm{X}_{17}$ & 0,99 & 142,857 \\
$\mathrm{X}_{4}$ & 0,96 & 26,316 & $\mathrm{X}_{18}$ & 0,99 & 142,857 \\
$\mathrm{X}_{5}$ & 0,95 & 20,833 & $\mathrm{X}_{19}$ & 1,00 & 500 \\
$\mathrm{X}_{6}$ & 0,85 & 6,579 & $\mathrm{X}_{20}$ & 1,00 & 1000 \\
$\mathrm{X}_{7}$ & 0,87 & 7,874 & $\mathrm{X}_{21}$ & 0,98 & 43,478 \\
$\mathrm{X}_{8}$ & 0,87 & 7,634 & $\mathrm{X}_{22}$ & 1,00 & $>1000$ \\
$\mathrm{X}_{9}$ & 0,89 & 8,850 & $\mathrm{X}_{23}$ & 1,00 & 200 \\
$\mathrm{X}_{10}$ & 1,00 & $>1000$ & $\mathrm{X}_{24}$ & 0,99 & 166,667 \\
$\mathrm{X}_{11}$ & 1,00 & $>1000$ & $\mathrm{X}_{25}$ & 0,72 & 3,623 \\
$\mathrm{X}_{12}$ & 1,00 & 1000 & $\mathrm{X}_{26}$ & 0,97 & 35,714 \\
$\mathrm{X}_{13}$ & 1,00 & $>1000$ & $\mathrm{X}_{27}$ & 0,94 & 15,385 \\
$\mathrm{X}_{14}$ & 1,00 & $>1000$ & $\mathrm{X}_{28}$ & 1,00 & 1000 \\
\hline \hline
\end{tabular}

Variabel yang ada sebagian besar memiliki nilai VIF yang tinggi. Hal ini bersesuaian dengan Tabel 4.4 yang mana nilai $\mathrm{R}^{2}$ yang diperoleh pun sangat besar bahkan ada yang mencapai $100 \%$. Maka dari itu untuk menghindari multikolinearitas yang tinggi, pemodelan akan dilakukan dalam masing-masing aspek diantaranya sosial, ekonomi, dan infrastruktur.

\section{Pemodelan dalam Aspek Sosial}

Pemodelan faktor-faktor aspek sosial yang diduga memengaruhi gini rasio pembangunan menggunakan 9 variabel dengan nilai VIF ditampilkan pada Tabel 5.

Tabel 5.

Nilai VIF 9 Variabel dalam Aspek Sosial

\begin{tabular}{cccccc}
\hline \hline Variabel & $R$-square & VIF & Variabel & $R$-square & $V I F$ \\
\hline $\mathrm{X}_{1}$ & 0,54 & 2,16 & $\mathrm{X}_{6}$ & 0,23 & 1,3 \\
$\mathrm{X}_{2}$ & 0,89 & 9,26 & $\mathrm{X}_{7}$ & 0,65 & 2,83 \\
$\mathrm{X}_{3}$ & 0,45 & 1,81 & $\mathrm{X}_{8}$ & 0,61 & 2,54 \\
$\mathrm{X}_{4}$ & 0,74 & 3,91 & $\mathrm{X}_{9}$ & 0,62 & 2,62 \\
$\mathrm{X}_{5}$ & 0,72 & 3,55 & & & \\
\hline \hline
\end{tabular}

Nilai VIF dari variabel di dalam aspek sosial memiliki nilai yang kurang dari 10, sehingga tidak perlu dilakukan PCA dalam pembentukan model. Model regresi linier yang terbentuk sebagai berikut,

$\hat{y}_{A S}=1,051+0,303 X_{1}+0,271 X_{2}+0,002 X_{3}+0,001 X_{4}$

$+3,5 \times 10^{-6} X_{5}-0,0118 X_{6}-0,001 X_{7}-0,0006 X_{8}+0,008 X_{9}$

Model gini rasio dalam persamaan 11 memiliki nilai dapat menjelaskan keragaman Gini rasio pembangunan sebesar $54,8 \%$ dan sisanya $45,2 \%$ dijelaskan oleh variabel lain di luar model yang terakomodir dalam nilai residual masingmasing kabupaten/kota. Nilai F-hitung sebesar 3,77 dengan P-value 0.003 yang mana nilai $P$-value ini lebih kecil dari 
taraf signifikan $20 \%$ sehingga diperoleh keputusan tolak $\mathrm{H}_{0}$ yang berarti variabel dalam aspek sosial berpengaruh signifikan terhadap gini rasio pembangunan secara serentak. Selanjutnya dilakukan pengujian efek spasial dari nilai residual yang diperoleh dari model sesuai persamaan 11 yang hasilnya ditampilkan dalam Tabel $6 .$.

Tabel 6

Hasil Pengujian Efek Spasial Variabel Aspek Sosial

\begin{tabular}{lcc}
\hline \hline \multicolumn{1}{c}{ Jeis Pengujian } & Value & P-Value \\
\hline Breusch-Pagan test & 7,233575 & 0,6128152 \\
Moran's I (error) & 1,9103607 & 0,0560867
\end{tabular}

Hasil pengujian morans'I memperoleh hasil Z-score sebesar 1,9103607 dengan $P$-value $(0,0560867)$. Karena $P$ value kurang dari taraf signifikan $20 \%$ maka diperoleh keputusan tolak $\mathrm{H}_{0}$ atau terdapat dependensi antar lokasi pengamatan sehingga dapat disimpulkan bahwa nilai gini rasio antar kabupaten/kota di Jawa Timur yang berdekatan lokasinya memiliki hubungan atau saling dependen satu sama lain. Adapun hasil BP Test diperoleh nilai P-value sebesar 0,61. nilai $P$-Value ini lebih dari taraf signifikan $20 \%$ sehingga diperoleh keputusan gagal tolak $\mathrm{H}_{0}$ yang berarti karakteristik gini rasio pembangunan kabupaten/kota di Jawa Timur homogen. Berdasarkan pengujian diperoleh hasil bahwa terdapat efek dependensi spasial antar lokasi sehingga untuk membuat model regresi spasial berdasarkan aspek sosial digunakan regresi spasial berbasis area.

Beberapa variabel aspek sosial dalam model regresi SEM dan SAR memiliki nilai $P$-value yang lebih dari taraf signifikan $20 \%$ sehingga dalam pengujian signifikansi parameter secara parsial masih terdapat variabel yang tidak berpengaruh signifikan dalam model SEM dan SAR yang dimiliki, sehingga perlu dilakukan pemodelan ulang dengan menggunakan metode backward selection. Terdapat total 7 variabel yang tidak signifikan dalam aspek sosial sehingga model yang terbentuk hanya menggunakan 2 variabel yaitu variabel $\mathrm{X}_{5}$ dan $\mathrm{X}_{9}$. Model regresi spasial terbaik untuk variabel aspek sosial adalah Spasial Error Model yang dipilih berdasarkan kriteria $\mathrm{R}^{2}$ yang terbesar dan nilai RMSE terkecil sesuai dengan tabel 7.

Tabel 7.

Pemilihan Model Terbaik

\begin{tabular}{lcc}
\multicolumn{3}{c}{ Pemilihan Model Terbaik } \\
\hline \hline Kriteria & SEM & SAR \\
\hline$R$-squared & 0,466566 & 0,454116 \\
$R M S E$ & 0,025713 & 0,026011 \\
\hline \hline
\end{tabular}

Model SEM memiliki nilai $\mathrm{R}^{2}$ yang lebih tinggi dari model SAR sebesar 46,6\% dan juga memiliki nilai RMSE terkecil sebesar 0,025713. sehingga Spatial Error Model merupakan model terbaik untuk memodelkan faktor-faktor sosial yang memengaruhi Gini Rasio pembangunan kabupaten/kota di Jawa Timur. Hasil pemodelan SEM dengan variabel signifikan ditampilkan dalam Tabel 8.

Tabel 8.

\begin{tabular}{lrlr}
\multicolumn{4}{c}{ Model SEM Terbaik untuk Variabel Aspek Sosial } \\
\hline \hline Variabel & Koefisien & \multicolumn{1}{c}{-value } & \multicolumn{1}{l}{-Value } \\
\hline Konstanta & 0,2573785 & 19,76631 & 0 \\
LAMBDA & 0,2932576 & 1,690056 & 0,0910171 \\
X $_{5}$ & $7,10 \mathrm{E}-06$ & 2,972 & 0,0029537 \\
$\mathrm{X}_{9}$ & 0,006708 & 2,184751 & 0,028907 \\
\hline
\end{tabular}

Koefisien dari pembobot spasial yang tercakup dalam nilai lambda memiliki $P$-value yang kurang dari taraf signifikan $20 \%$ sehingga diperoleh keputusan tolak $\mathrm{H}_{0}$ yang berarti efek spasial lag maupun efek spasial error dalam masing-masing model siginifikan berpengaruh terhadap nilai gini rasio pembangunan. Persamaan lengkapnya untuk Spatial Error Model faktor aspek sosial ditampilkan dalam persamaan 4.2,

$$
\hat{y}_{i}=0,2573+0,293 \sum_{\mathrm{j}=1, \mathrm{j} \neq \mathrm{i}}^{38} \mathrm{w}_{\mathrm{ij}} u_{j}+7,10 \times 10^{-6} X_{5}+0,006 X_{9}
$$

Pada persamaan 13 ditampilkan Spatial Error Model untuk Kota Surabaya, yang mana dalam model ini dipengaruhi oleh nilai bobot antara Kota Surabaya dan Kabupaten Gresik serta Kabupaten Sidoarjo dan nilai residual masing-masing Kabupaten Sidoarjo maupun Kabupaten Gresik.

$$
\begin{aligned}
& \hat{y}_{i}=0,2573+0,293 *\left(w_{\text {surabaya,gresik }} * u_{\text {Gresik }}+\right. \\
& \left.w_{\text {Surabaya_Sidoarjo }} * \mathrm{u}_{\text {Sidoarjo }}\right)+7,10 \times 10^{-6} X_{5}+0,006 X_{9}
\end{aligned}
$$

Adapun interpretasi dari model yang terbentuk pada persamaan 13 adalah sebagai berikut,

- $0,293 *\left(w_{\text {surabayagresik }} * u_{\text {Gresik }}+w_{\text {Surabaya,Sidoarjo }} * \mathrm{u}_{\text {Sidoarjo }}\right)$

Kedua nilai error dari Kabupaten Gresik dan Kabupaten Sidoarjo berpengaruh terhadap model SEM aspek sosial Kota Surabaya sebesar 0,293.

- $7,10 \times 10^{-6} \mathrm{X}_{5}$ (Kepadatan Penduduk)

Kepadatan Penduduk yang mencapai $10^{5}$ atau 10.000 jiwa/ $\mathrm{Km}^{2}$ akan meningkatkan nilai gini rasio Kota Surabaya sebesar 0,71 .

- $\quad 0,006 \mathrm{X}_{9}$ (Tingkat Pengangguran Terbuka)

Tingkat pengangguran terbuka yang mencapai $10 \%$ akan meningkatkan nilai gini rasio Kota Surabaya sebesar 0,06 .

2. Pemodelan dalam Aspek Ekonomi

Pemodelan faktor-faktor dalam aspek ekonomi yang diduga memengaruhi gini rasio pembangunan menggunakan 16 variabel. Adapun Nilai VIF dari 16 variabel tersebut ditampilkan pada Tabel 9.

Tabel 9.

Nilai VIF Variabel Prediktor Aspek Ekonomi

\begin{tabular}{crrcrr}
\hline \hline Variabel & $R$-Squared & \multicolumn{1}{c}{ VIF } & Variabel & $R$-Squared & \multicolumn{1}{c}{ VIF } \\
\hline $\mathrm{X}_{10}$ & 0,986 & 71,43 & $\mathrm{X}_{18}$ & 0,92 & 13,89 \\
$\mathrm{X}_{11}$ & 0,981 & 52,63 & $\mathrm{X}_{19}$ & 0,80 & 5,13 \\
$\mathrm{X}_{12}$ & 0,992 & 125,00 & $\mathrm{X}_{20}$ & 0,84 & 6,25 \\
$\mathrm{X}_{13}$ & 0,778 & 4,50 & $\mathrm{X}_{21}$ & 0,80 & 5,08 \\
$\mathrm{X}_{14}$ & 0,958 & 23,81 & $\mathrm{X}_{22}$ & 0,86 & 7,19 \\
$\mathrm{X}_{15}$ & 0,956 & 22,73 & $\mathrm{X}_{23}$ & 0,99 & 100,00 \\
$\mathrm{X}_{16}$ & 0,931 & 14,49 & $\mathrm{X}_{24}$ & 0,98 & 83,33 \\
$\mathrm{X}_{17}$ & 0,863 & 7,30 & $\mathrm{X}_{25}$ & 0,36 & 1,58 \\
\hline \hline
\end{tabular}

Nilai VIF dari beberapa variabel di dalam aspek ekonomi besarnya lebih dari 10, sehingga terdapat kasus multikolinearitas. Dalam hal ini Principal Component Analysis dapat diterapkan untuk mengatasi kasus multikolinearitas yang terjadi.

Tabel 10

Hasil Principal Component Analysis

\begin{tabular}{lrrrrr}
\multicolumn{7}{c}{ Hasil Principal Component Analysis } \\
\hline \hline Eigenvalue & 6,2975 & 3,2801 & 1,2723 & 1,1389 & 1,0509 \\
Proportion & 0,394 & 0,205 & 0,08 & 0,071 & 0,066 \\
Cumulative & 0,394 & 0,599 & 0,678 & 0,749 & 0,815 \\
\hline \hline
\end{tabular}

Principal Component Analysis yang dilakukan membentuk 16 komponen utama. Lalu dipilih komponen utama yang memiliki nilai eigen lebih dari 1 seperti yang ditunjukkan pada Tabel 10. 5 komponen utama yang terpilih sudah mampu menjelaskan proporsi keragaman variabel prediktor dengan total sebesar $81,5 \%$. Selanjutnya dilakukan pemodelan regresi linier berganda kembali dan pengujian efek spasial. 
Tabel 11.

Hasil Pengujian Efek Spasial Variabel Aspek Ekonomi

\begin{tabular}{lcc}
\hline \multicolumn{1}{c}{ Jeis Pengujian } & Value & $P$-Value \\
\hline Breusch-Pagan test & 0,23 & 0,631 \\
Moran's I (error) & 0,317 & 0,751 \\
\hline
\end{tabular}

Hasil pengujian morans'I yang dilakukan terhadap nilai error model aspek ekonomi memperoleh hasil Z-score (Value) sebesar 0,23 dengan p-value $(0,631)$. Karena $P$ value yang diperoleh lebih dari taraf signifikan $20 \%$ maka tidak terdapat dependensi antar residual lokasi pengamatan. Adapun hasil BP Test diperoleh nilai P-value sebesar 0,751. nilai $P$-value ini lebih dari taraf signifikan $20 \%$ yang berarti karakteristik residual gini rasio pembangunan kabupaten/kota di Jawa Timur homogen.

Untuk mendapatkan model terbaik dengan komponen yang signifikan dapat dilakukan dengan menggunakan metode Backward Selection. Secara berturut-turut, komponen utama yang dikeluarkan dari model adalah SE4, SE3, SE2, dan SE5 diperoleh hasil pemodelan regresi dengan komponen yang tersisa berikut,

$$
\hat{y}_{A E}=0,3+0,00982 P C 1
$$

dengan, $\hat{y}_{A E}$ adalah nilai prediksi Gini Rasio dengan aspek ekonomi.

Model gini rasio dalam persamaan 14 memiliki nilai $\mathrm{R}^{2}$ Sebesar 0,477 yang berarti model tersebut dapat menjelaskan keragaman gini rasio pembangunan sebesar 47,7\% dan sisanya $42,3 \%$ dijelaskan oleh variabel lain di luar model yang terakomodir dalam nilai residual masing-masing kabupaten/kota. Selain itu diperoleh nilai F-hitung sebesar 32,87 dengan nilai $P$-value ini kurang dari taraf signifikan $20 \%$ sehingga diperoleh keputusan tolak $\mathrm{H}_{0}$ yang berarti komponen utama berpengaruh signifikan terhadap gini rasio pembangunan. Selanjutnya dilakukan transformasi kembali ke dalam variabel asal yang ditampilkan dalam persamaan 15 .

$$
\begin{aligned}
& \hat{y}_{A E, i}=0,3-0,002 X_{10}-0,0021 X_{1 \Gamma}-0,00059 X_{12}+0,00029 X_{13} \\
& +0,0033 X_{14}+0,003 X_{15}+0,0031 X_{16}++0,003 X_{17}+0,0029 X_{18} \\
& +0,00048 X_{19}+0,002 X_{20}+0,0028 X_{21}+0,002 X_{22}+0,003 X_{23} \\
& +0,003 X_{24}+0,0012 X_{25}
\end{aligned}
$$

Model regresi linier untuk faktor aspek ekonomi yang memengaruhi gini rasio pembangunan di Jawa Timur memiliki nilai $\mathrm{R}^{2}$ sebesar 0,477 serta nilai RMSE 0,026. Sehingga dengan model faktor ekonomi ini mampu menjelaskan keragaman gini rasio pembangunan di Jawa Timur sebesar 47,7\% sedangkan sisanya dijelaskan oleh faktor lain diluar model. Selain itu juga dilakukan pengecekan asumsi dari model ini. P-Value yang diperoleh dari uji Kolmogorov Smirnov >0.150 yang dapat disimpulkan bahwa nilai error dari model yang terbentuk mengikuti distribusi normal sehingga asumsi model regresi yang pertama terpenuhi. Asumsi selanjutnya adalah homogenitas varians dengan menggunakan Uji heterokedastisitas. Dari hasil tersebut diperoleh nilai p-value dari variabel prediktor sebesar 0,442 yang mana nilai ini lebih dari taraf signifikan $20 \%$ sehingga diperoleh keputusan gagal tolak $\mathrm{H}_{0}$ yang berarti varians error dari model sudah homogen. Asumsi yang ke-3 adalah asumsi residual yang independen. Secara visual dalam Gambar 4. terlihat bila nilai residual menyebar dan tidak membentuk pola sehingga dapat disimpulkan bahwa residual dari model aspek ekonomi nilainya independen. Hal ini didukung dengan hasil pengujian efek dependensi spasial sebelumnya yang menunjukkan bahwa nilai residual antar pengematan tidak mempengaruhi satu sama lain. Sehingga dapat disimpulkan model aspek ekonomi sudah memenuhi asumsi IIDN.

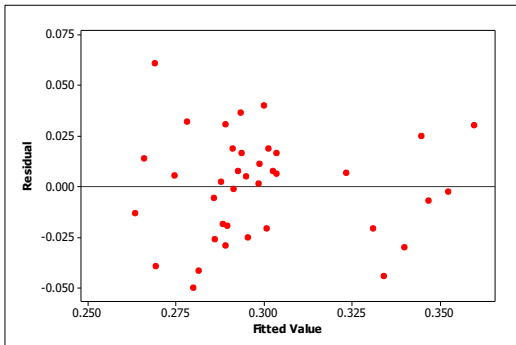

Gambar 4. Hasil Plot Residualuntuk Pengecekan Asumsi Independen

Adapun interpretasi dari model yang terbentuk pada persamaan 15 adalah sebagai berikut,

- $\quad-0,002 X_{10}$ ( PDRB Pertanian Kehutanan dan Perikanan) Peningkatan PDRB bidang usaha pertanian, Kehutanan,dan Perikanan sebesar 1 satuan akan menurunkan nilai gini rasio kabupaten/kota di Jawa Timur sebesar 0,002. Hal ini dapat terjadi salah satunya karena sebagian besar masyarakat di Indonesia yang mendalami bidang usaha ini berada pada kelas ekonomi mengengah ke bawah.

- $\quad 0,003 \mathrm{X}_{17}$ (PDRB Real Estate)

Peningkatan PDRB Real Estate sebesar 1 satuan akan meningkatkan nilai gini rasio kabupaten/kota di Jawa Timur sebesar 0,003. Hal ini dapat terjadi salah satunya karena bidang usaha real estate tergolong bidang usaha yang besar dan sebagian besar merupakan bidang usaha dari 1 keluarga.

Interpretasi tersebut berlaku saat variabel lainnya bernilai konstan. 3 dari 16 variabel aspek ekonomi berdasarkan model dalam persamaan 15 memiliki nilai koefisien yang bertanda negative yang berarti variabel tersebut berperan dalam menurunkan angka Gini Rasio. Sedangkan 12 variabel sisanya yang bertanda positif berperan dalam meningkatkan nilai gini rasio pembangunan di Jawa Timur.

\section{Pemodelan dalam Aspek Infrastruktur}

Pemodelan faktor-faktor dalam aspek Infrastruktur yang diduga memengaruhi gini rasio pembangunan menggunakan 4 variabel. Adapun Nilai VIF dari 4 variabel tersebut ditampilkan pada Tabel 12.

Tabel 12.

Nilai VIF Variabel Prediktor Aspek Infrastruktur

\begin{tabular}{ccc}
\hline \hline Variabel & $R$-Squared & $V I F$ \\
\hline $\mathrm{X}_{26}$ & 0,16 & 1,195 \\
$\mathrm{X}_{27}$ & 0,46 & 1,859 \\
$\mathrm{X}_{28}$ & 0,34 & 1,515 \\
$\mathrm{X}_{29}$ & 0,32 & 1,477 \\
\hline \hline
\end{tabular}

Nilai VIF dari variabel di dalam aspek infrastruktur memiliki nilai yang kurang dari 10, sehingga tidak perlu dilakukan PCA dalam pembentukan model. Model regresi linier yang terbentuk untuk variabel dalam aspek infrastruktur yang diduga memengaruhi gini rasio pembangun teangkum dalam Tabel 13

Tabel 13.

Analisis Regresi Variabel Aspek Infrastruktur

\begin{tabular}{ccc}
\hline \hline Variabel & Koefisien & P-Value \\
\hline Konstanta & 0.25946 & 0 \\
$\mathrm{X}_{26}$ & 2.062 & 0.33 \\
$\mathrm{X}_{27}$ & 22.67 & 0.047 \\
$\mathrm{X}_{28}$ & 0.1091 & 0.688 \\
$\mathrm{X}_{29}$ & 0.1448 & 0.549 \\
\hline \hline
\end{tabular}


Model gini rasio dalam Tabel 13 memiliki nilai $\mathrm{R}^{2}$ sebesar 0,278 yang berarti model tersebut dapat menjelaskan keragaman gini rasio pembangunan sebesar $27,8 \%$. Selain itu diperoleh nilai F-hitung sebesar 3.18 dengan P-value 0.026 yang mana nilai $P$-value ini lebih kecil dari taraf signifikan $20 \%$ yang berarti variabel dalam aspek infrastruktur berpengaruh signifikan terhadap gini rasio pembangunan secara serentak. Beberapa variabel aspek infrastruktur dalam model regresi memiliki nilai $P$-value yang lebih dari taraf signifikan $20 \%$ yang dapat dilihat pada Tabel 4.17 sehingga dalam pengujian signifikansi parameter secara parsial masih terdapat variabel yang tidak berpengaruh signifikan dalam model yang dimiliki, sehingga perlu dilakukan pemodelan ulang dengan menggunakan metode backward selection. Terdapat total 3 variabel yang tidak signifikan dalam aspek infrastruktur sehingga model yang terbentuk hanya menggunakan 1 variabel yaitu variabel $\mathrm{X}_{27}$.

$$
\hat{y}_{A I}=0,269+26,87 \mathrm{X}_{27}
$$

Selanjutnya dilakukan pengujian efek spasial dari nilai residual yang diperoleh dari model sesuai persamaan 16 yang hasilnya ditampilkan dalam Tabel 14.

Tabel 14.

Hasil Pengujian Efek Spasial Variabel Aspek Infrastruktur

\begin{tabular}{lcc}
\hline \hline \multicolumn{1}{c}{ Jeis Pengujian } & Value & $P$-Value \\
\hline Breusch-Pagan test & 0,022 & 0,88 \\
Moran's I (error) & 1,19 & 0,23 \\
\hline \hline
\end{tabular}

Hasil pengujian Morans'I memperoleh hasil Z-score (Value) sebesar 1,19 dengan $p$-value $(0,23)$. Karena $P$-value yang diperoleh kurang dari taraf signifikan 20\% maka tidak terdapat dependensi antar lokasi pengamatan. Adapun hasil BP Test diperoleh nilai $P$-value sebesar 0,88 . Nilai $P$-Value ini lebih dari taraf signifikan $20 \%$ yang berarti karakteristik gini rasio pembangunan kabupaten/kota di Jawa Timur homogen. Berdasarkan pengujian efek spasial yang dilakukan diperoleh hasil bahwa tidak terdapat efek spasial antar lokasi sehingga untuk membuat model regresi berdasarkan aspek infrastruktur digunakan regresi linier OLS sesuai persamaan 16 sebelumnya.

Tabel 15 .

Analisis Regresi Variabel Infrastruktur yang signifikan

\begin{tabular}{cccc}
\hline \hline Variabel & Koefisien & $\mathrm{T}$ & $\mathrm{P}$ \\
\hline Konstanta & 0.26996 & 26.7 & 0 \\
Pengadaan & 26.876 & 3.41 & 0.002 \\
\hline
\end{tabular}

Model Regresi OLS dalam Tabel 15 memiliki nilai $\mathrm{R}^{2}$ sebesar 24,4\% dan juga memiliki nilai RMSE sebesar 0,031. Variabel $\mathrm{X}_{27}$ atau variabel pengadaan air dan pengelolaan sampah memiliki nilai P-Value sebesar 0,002. Nilai tersebut kurang dari taraf signifikan $20 \%$ sehingga variabel berpengaruh signifikan terhadap model. Dengan nilai koefisien sebesar 26,87 maka setiap peningkatan 1 satuan variabel $\mathrm{X}_{27}$ akan meningkatkan nilai gini rasio sebesar 26,87. Sehingga untuk aspek infrastruktur secara umum akan meningkatkan gini rasio pembangunan kabupaten/kota di Jawa Timur.

\section{KESIMPULAN}

\section{A. Kesimpulan}

Ketimpangan Pendapatan yang terjadi di Jawa Timur rata rata termasuk dalam kondisi ketimpangan Sedang. Model regresi spasial terbaik untuk gini rasio pembangunan kabupaten/kota di Jawa Timur adalah Spatial Error Model. Model memiliki nilai $\mathrm{R}^{2}$ sebesar $46,6 \%$ dan nilai $\mathrm{RMSE}$ terkecil 0,025713. Adapun variabel yang signifikan adalah variabel yang berasal dari aspek sosial yakni kepadatan penduduk dan tingkat pengangguran terbuka. Kedua variabel tersebut berkontribusi dalam meningkatkan nilai gini rasio pembangunan. Adapun pengaruh dari aspek infrastruktur dan aspek ekonomi terhadap gini rasio pembangunan kabupaten/kota di Jawa Timur tidak bergantung pada aspek spasialnya.

\section{B. Saran}

Saran yang dapat diberikan berdasarkan hasil penelitian ini adalah mengupayakan kembali penuntasan masalah kepadatan penduduk yang mana persebarannya tidak merata serta penurunan tingkat pengangguran terbuka untuk menekan nilai Gini Rasio Pembangunan di Jawa Timur.

\section{DAFTAR PUSTAKA}

[1] T. Tambunan, Perekonomian Indonesia. Jakarta: Ghalia Indonesia, 2001.

[2] M. P. Todaro and S. C. Smith, Pembangunan Ekonomi di Dunia Ketiga. Jakarta: Erlangga, 2004.

[3] ABM and M. Agastya, Arab Spring. Yogyakarta: IRCiSoD, 2013.

[4] R. E. Walpole, Pengantar Statistika. Jakarta: PT Gramedia Pustaka Utama, 1993.

[5] D. N.R and S. H., Analisis Regresi Terapan. Jakarta: Gramedia Pustaka Utama, 1992.

[6] D. N. Gujarati, Basic Econometrics, 4th ed. New York: Mc Graw Hill, 2004.

[7] J. Persada, Principal Component Analysis. New York: Springer-Verlag, 1986.

[8] R. A. Johnson and D. W. Wichern, Applied Multivariate Statistical Analysis. New Jersey: Prentice Hall, 2007.

[9] J. LeSage, "Spatial Econometric," IEEE Trans. Neural Networks, vol. 4, pp. 570-578, 1993.

[10] L. Anselin, Spatial Econometrics Method and Models. Netherland: Khiwer Academic Publishers, 1988. 